\title{
Epidemiological Survey of Dental Fear and Anxiety in Children Living in Transylvania
}

\author{
Gyergyay Réka1, Székely Melinda², Mártha Krisztina ${ }^{1}$ \\ ${ }^{1}$ Department of Pedodontics and Orthodontics, Faculty of Dental Medicine, University of Medicine and Pharmacy, Tîrgu-Mureș \\ 2 Department of Morphology of Teeth and Dental Arches; Technology of Dental Prosthesis and Dental Materials, Faculty of Dental Medicine, University of \\ Medicine and Pharmacy, Tîrgu-Mureș
}

\begin{abstract}
Aims: The objectives of the present survey were: 1) a systematic epidemiological investigation of dental fear and anxiety among children living in the central part of Romania and 2) to identify the most fearful aspects of dental care perceived by these children.

Methods: In this cross-sectional study 406 schoolchildren, 170 males and 263 females, aged 11-18 yearsfrom two cities, Tîrgu Mureș and Sfintu Gheorghe were assessed. The subjects' dental fear was evaluated with the Romanian versions of Corah's Dental Anxiety Scale (MDAS) and Kleinknecht's Dental Fear Survey (DFS), the anxiety level with Spielberger's State and Trait Anxiety Inventory (STAI-S, STAI-T) and their opinion about dentists with Getz's Dental Beliefs Scale (DBS). Questionnaires were completed anonymously at school. The study was approved by theResearch Ethics Committeeof the University of Medicine and Pharmacy Tîrgu Mureș. For statistical analysis t-test, one-way ANOVA and Pearson's correlation test were used by SPSS/PC statistics v. 17.0.

Results: The mean $( \pm$ SD) scores of the surveyed subjects (mean age 15.69 \pm 2.06 years) were high: MDAS 10.65 $( \pm 4.5)$, DFS $38.68( \pm 15.1)$, DBS $36.93( \pm 11.9)$, STAI-S $37.90( \pm 10.9)$ and STAI-T $41.04( \pm 9.9)$, respectively. There was a strong positive Pearson-correlation between MDAS and DFS scores ( $r=0.73 ; p \leq 0.01)$ and a somewhat lower correlation between these scales and the general anxiety scores. Except for DBS, statistically significantly higher scores were found in females for every questionnaire (t-test, $p \leq 0.05)$. The 11-year-old group presented the lowest scores in every case, while the peak was around 14 years. Age was a statistically significant factor only in case of DBS, STAI-S and STAI-T (one-way ANOVA, $\mathrm{p}<0.05$ ). Drilling and injection were considered the most fearful moments of a dental treatment. Subjects claimed dental practitioners working under time pressure and communication deficiencies.

Conclusions: Having their special features, our findings were consistent with the local and international data. The subjects claim lack of time and communication deficiencies with the dentists. Identifying the reasons of dental fear and anxiety, might lead to solutions of avoidance or control.
\end{abstract}

Keywords: children, Romania, dental fear and anxiety

Received: 25 June 2014 / Accepted 12 August 2014

\section{Introduction}

Dental fear and anxiety (DFA) is a common occurrence characterized by an essential and inevitable emotion that appears as a response to dental procedures [1]. The fenomenon of anxiety and fear have been defined in many ways in the literature. In 1970, Spielberger made a distinction between the more temporary condition of 'state anxiety' and the more longstanding and general 'trait anxiety' [2]. Both aspects are combined in case of DFA, which varies in intensity from one patient to another, ranging from a simple nervousness to dental anxiety, which is a sentiment of fear often unjustified and can disappear spontaneously or amplify, becoming dental phobia.

Dental fear and anxiety remains a barrier to dental care for a consistent proportion of the population [3], it is constantly met among children younger than three years, but it also appears in the older ones [1]. A great number of researches regarding DFA among children using a large variety of methods have been performed all around the world. The results of these studies are extremely diversified, sometimes even contradictory.
Romanian authors have assessed children in different circumstances and with different methods. Mărginean and Filimon have validated the Romanian versions of Modified Dental Anxiety Scale and Dental Fear Survey and they have applied them on a population of young adults $[4,5]$. Lazar et al. have also used the Modified Dental Anxiety Scale on a representative sample of the 14-18-year-old adolescents in Timişoara [6]. Răducanu et al. have assessed 3 to 18- year-old children from Bucharest with Facial Images Scale (FIS) for dental fear and anxiety and Frankl Behaviour Rating Scale (FBRS) for behavioural pattern [7]. In case of a smaller group of orthodontic patients aged 9-18years, Vaida et al. applied STAI-S and STAI-T [8]. Markovics et al. made an epidemiological evaluation of the 12-19-year-old Hungarian minority from Romania living near the borders of Hungary [9], applying the same long standing methods as their collegues over the borders [1016]. In Tîrgu Mureş several studies have been performed but only on the adult population, among which Cerghizan's work was the most comprehensive in 2008 [17-19]. Although the prevalence of dental caries in children from Romania is alarming, there is no information about the level of DFA of children living in the middle part of the country. 
Against this background, the aims of this study were: to expand the epidemiological evaluation of DFA among children in Romania (living in the central part of the country from where no data exists yet) using a systematic methodology and to highlight those aspects of dental care which cause the most problems to children in the process of making it esasier to support.

\section{Methods}

The subjects of our cross sectional questionnaire-based randomized study, which took place in June 2013, were Romanian children living in two cities from Transylvania situated in the central part of Romania, Tîrgu Mureş and Sfintu Gheorghe. 406 schoolchildren were involved,196 from Tîrgu Mureş and 210 from Sfintu Gheorghe, 170 males and 263 females, aged 11-18 years.

Participation in the survey was anonymous and voluntary. Appropriate information about the study had been provided to the participants and also to their parents, who gave their written consent. The study was approved by the Research Ethics Committeeof the Universcity of Medicine and Pharmacy Tîrgu Mureş (42/14.03.2013).

Dental fear was measured with Corah`s Modified Dental Anxiety Scale (MDAS) [20] and Kleinknecht's Dental Fear Survey (DFS) [21, 22], which have been translated to Romanian and validated in a pervious survey [4, 5].Constitutional anxiety level was measured also by the Romanian versions of Spielberger`s State and Trait Anxiety Inventory (STAI-S, STAI-T) [2]. The opinion of the children about dentists was measured with Getz's Dental Belief Scale (DBS) [23], translated to Romanian by us.

All the questionnaireswere self-applied and completed in groups at school at one occasion, after lessons. For statistical analysis t-test, one-way ANOVA and Pearson's correlation test were used by the SPSS/PC Statistics 17.0 software (SPSS, Inc. Chicago, IL) with the level of significance set at $\mathrm{p} \leq 0.05$.

\section{Results}

Table I. shows the Pearson-correlations between the scales used in this survey. There was a statistically significant positive correlation $(p \leq 0.01)$ between the values in each case. Moreover, the correlations between the dental fear and dental anxiety scales (DAS, DFS) and the anxiety state and trait scales (STAI-S and STAI-T), respectively, were stronger than the correlation of the two groups of scales. The correlation of DBS with the dental fear and anxiety state scales was somewhat lower. Furthermore Chronbach`s alpha value for the five scales was 0.754 , which justifies the use of these questionarries for the same purpose. Table II. shows that the inner consistency of the survey would decrease if we removed any of the used scales.

The mean $( \pm$ S.D) age of the surveyed sample was 15.69 $( \pm 2.06)$ years. Table III. presents the main information about the subjects: gender, age and the scale scores.
In case of MDAS, 228 subjects (56.16\%)of the investigated sample presented lack of fear (MDAS score $\leq 10)$, 155 subjects (38.18\%) accused low (MDAS score between 11-18), while only 23 children (5.66\%) showed high levels

Table I. Pearson-correlations between the scores of dental fear and anxiety:

\begin{tabular}{cccccc}
\hline & MDAS & DFS20 & DBS & STAI-S & STAI-T \\
\hline DASQ & 1.000 & & & & \\
DFS20 & $0.768^{\star *}$ & 1.000 & & & \\
DBS & $0.308^{\star *}$ & $0.364^{\star *}$ & 1.000 & & \\
STAIS & $0.405^{\star \star}$ & $0.464^{\star *}$ & $0.373^{\star *}$ & 1.000 & \\
STAIT & $0.290^{* *}$ & $0.409^{\star *}$ & $0.408^{\star *}$ & $0.674^{\star *}$ & 1.000 \\
\hline${ }^{* *} \leq 0.01$ & & & & &
\end{tabular}

Table II. Cronbach alpha values:

\begin{tabular}{cccccc}
\hline $\begin{array}{c}\text { Cronbach`s alpha } \\
=\mathbf{0 . 7 5 4}\end{array}$ & MDAS & DFS & DBS & STAI-S & STAI-T \\
\hline $\begin{array}{c}\text { Cronbach's alpha } \\
\text { if item deleted }\end{array}$ & 0.746 & 0.711 & 0.731 & 0.666 & 0.681 \\
\hline
\end{tabular}

Table III. Dental fear and anxiety scores of Romanian children aged 11-18 years:

\begin{tabular}{|c|c|c|c|c|c|c|c|}
\hline $\begin{array}{l}\text { Number } \\
\text { of sub- } \\
\text { jects } \\
\text { (n) }\end{array}$ & $\begin{array}{l}\text { Fe- } \\
\text { male }\end{array}$ & Male & MDAS & DFS & DBS & $\begin{array}{c}\text { STAI- } \\
\mathrm{S}\end{array}$ & $\begin{array}{c}\text { STAI- } \\
\mathbf{T}\end{array}$ \\
\hline 406 & 236 & 170 & $\begin{array}{c}10.65 \\
\pm 4.5\end{array}$ & $\begin{array}{l}38.68 \\
\pm 15.1\end{array}$ & $\begin{array}{l}36.93 \\
\pm 11.9\end{array}$ & $\begin{array}{l}37.90 \\
\pm 10.9\end{array}$ & $\begin{array}{c}41.04 \\
\pm 9.9\end{array}$ \\
\hline
\end{tabular}

of dental anxiety (MDAS score $\geq 19$ ). In the same time, in case of DFS 187 (46.06\%) of the subjects indicated low or no fear at all (DFS $\leq 33), 168(41.38 \%)$ presented moderate fear (MDAS: 34-58), while 51 (12.56\%) had high levels of dental fear (DFS $\geq 59)$.

Dental fear and anxiety scores according to gender and age can be seen in Table IV. Females showed significantly higher values in case of every scale except for DBS, which was slightly lower than males', but statistically not significant $(\mathrm{p} \leq 0.05$, independent $\mathrm{t}$ test).

From the viewpoint of age, our results show, that the 14-year-old group presented the highest values except for DBS (Table IV). In case of the dental fear and anxiety scales, the 14-year-old group definitely marked the peak, from where the younger children showed even lower scores than the older ones. It is very interesting that the youngest ones, the 11-year-olds seemed to be the bravest, from where on, the anxiety and fear gradually increased until reaching its peak at 14 , than it slightly decreased and remained on the same level in the older groups of age. This observation is also valid for the general anxiety scales ( $\mathrm{Ta}-$ ble IV), as the scores of STAI-S and STAI-T showed a very similar distribution. We measured the lowest DBS scores at the age of 11 and the highest at 16, the other groups moved around the same level (Table IV). Age seemed to be a statistically significant factor only in case of DBS, STAI-S and STAI-T (one-way ANOVA, $\mathrm{p}<0.05$ ).

Analysing the obtained data from the two cities the survey was performed in (Table V.) - Tîrgu Mureş and Sfîntu 
Table IV. The subjects' dental fear and anxiety scores according to the gender and age, respectively:

\begin{tabular}{|c|c|c|c|c|c|c|}
\hline Group & (n) & DASQ & DFS 20 & DBS & STAI-S & STAI-T \\
\hline \multicolumn{7}{|l|}{ Gender } \\
\hline Female & 236 & $11.07 \pm 4.4$ & $40.61 \pm 14.0$ & $36.89 \pm 11.1$ & $39.24 \pm 10.7$ & $42.74 \pm 9.7$ \\
\hline male & 170 & $10.07 \pm 4.7$ & $36.01 \pm 16.2$ & $36.98 \pm 11.32$ & $36.03 \pm 11.1$ & $38.68 \pm 9.8$ \\
\hline \multicolumn{7}{|c|}{ Age (years) } \\
\hline 11 & 13 & $8.31 \pm 4.1$ & $30.69 \pm 11.9$ & $29.84 \pm 10$ & $27.15 \pm 4.6$ & $32.23 \pm 11.7$ \\
\hline 12 & 32 & $9.75 \pm 4$ & $35.68 \pm 16.4$ & $34.12 \pm 12$ & $31.40 \pm 7$ & $37.03 \pm 11.2$ \\
\hline 13 & 43 & $9.93 \pm 4.7$ & $37.86 \pm 15.6$ & $32.44 \pm 11.1$ & $35.27 \pm 12.2$ & $36.88 \pm 8.4$ \\
\hline 14 & 21 & $11.33 \pm 4.3$ & $41.14 \pm 16.7$ & $35.95 \pm 13.6$ & $40 \pm 13.2$ & $43.47 \pm 11.7$ \\
\hline 15 & 32 & $10.78 \pm 4.3$ & $37.21 \pm 13.6$ & $36.31 \pm 11.4$ & $39.96 \pm 9.9$ & $43.25 \pm 10.7$ \\
\hline 16 & 67 & $10.95 \pm 4.8$ & $39.43 \pm 14.7$ & $40.28 \pm 11.2$ & $39.61 \pm 10.7$ & $41.67 \pm 8.9$ \\
\hline 17 & 124 & $10.97 \pm 4.5$ & $39.89 \pm 16.2$ & $37.35 \pm 10$ & $38.52 \pm 10.7$ & $42.19 \pm 9$ \\
\hline 18 & 74 & $10.82 \pm 4.6$ & $39.12 \pm 13.4$ & $38.79 \pm 10.9$ & $40.04 \pm 10.8$ & $42.62 \pm 9.9$ \\
\hline
\end{tabular}

Table V. Dental fear and anxiety scores of Romanian children from two different cities aged 11-18 years $(n=406)$ :

\begin{tabular}{cccccc}
\hline & Numberof subjects & DAS & DFS & DBS & STAI-S \\
\hline Targu-Mures & 196 & $9.91 \pm 4.24$ & $36.18 \pm 14.50$ & $33.94 \pm 11.23$ & $35.37 \pm 10.75$ \\
Sfantu-Gheorghe & 210 & $11.35 \pm 4.70$ & $41.03 \pm 15.40$ & $39.72 \pm 10.41$ & $40.26 \pm 10.65$ \\
\hline
\end{tabular}

Gheorghe -it was found that in all scales the differences were significantly higher in children from Sfintu Gheorghe (one-way ANOVA, $\mathrm{p}<0.05$ ).

Table VI. shows the scores of each question of the DFS from the viewpoint of gender and domicile. The Cronbach alpha value for DFS was 0.938 , high enough to consider that the subjects` collaboration was good. It was observed, that the questions referring to the injection were scored the highest and those about the drill were somewhat lower but still high. Besides these, the judgement of dentistry as a whole (20th question) was still high, but it did not reach the level of the most fearful part of the process, getting an injection. We observed statistically significant differences on the one hand from the viewpoint of gender between questions no.1, 3, 4, 7, 14-18 and 20, respectively, and on the other hand from the viewpoint of domicile between questions no. 1-5, 7,8,10,12,13,16, 17 and19,respectively (independent $\mathrm{t}$-test, $\mathrm{p}<0.05$ ). Age is a significant factor from a mathematical point of view in case of questions no. 1,3 and 7 (one-way ANOVA, $\mathrm{p}<0.05$ ).

Cronbach alpha was 0.840 for DBS. In Table VII. can be seen the scores given to each question of the DBS dissociated by gender and domicile. The most objected questions point to the lack of time the dentist deals with when treating patients. Furthermore other disapprovals deriving from the communication deficiencies between patient and

Table VI. DFS question scores $(n=406)$ :

\begin{tabular}{|c|c|c|c|c|c|}
\hline DFS & $\begin{array}{l}\text { Female } \\
(n=236)\end{array}$ & $\begin{array}{c}\text { Male } \\
(n=170)\end{array}$ & $\begin{array}{l}\text { Sfantu Gheorghe } \\
\qquad(n=210)\end{array}$ & $\begin{array}{l}\text { Targu Mures } \\
(n=196)\end{array}$ & $\begin{array}{l}\text { Total score } \\
(\mathrm{n}=406)\end{array}$ \\
\hline \multicolumn{6}{|l|}{ Avoiding dental care } \\
\hline 1. unable to get an appointment & $1.77 \pm 1.13$ & $1.53 \pm 1.11$ & $1.90 \pm 1.23$ & $1.42 \pm 0.93$ & $1.67 \pm 1.12$ \\
\hline 2. unable to go to the appointment & $1.34 \pm 0.78$ & $1.31 \pm 0.87$ & $1.41 \pm 0.93$ & $1.23 \pm 0.68$ & $1.33 \pm 0.82$ \\
\hline \multicolumn{6}{|c|}{ Autonomic nervous system activity during treatment } \\
\hline 3. muscle tension & $2.61 \pm 1.08$ & $2.12 \pm 1.09$ & $2.59 \pm 1.07$ & $2.21 \pm 1.11$ & $2.41 \pm 1.11$ \\
\hline 5. sweating & $1.62 \pm 0.94$ & $1.66 \pm 0.97$ & $1.74 \pm 1.00$ & $1.53 \pm 0.88$ & $1.64 \pm 0.95$ \\
\hline 6. nausea & $1.28 \pm 0.69$ & $1.30 \pm 0.80$ & $1.34 \pm 0.81$ & $1.23 \pm 0.65$ & $1.29 \pm 0.74$ \\
\hline 7.quick pulse & $2.48 \pm 1.21$ & $1.98 \pm 1.17$ & $2.54 \pm 1.17$ & $1.98 \pm 1.20$ & $2.27 \pm 1.22$ \\
\hline \multicolumn{6}{|l|}{ Fears caused by situations and stimulus } \\
\hline 8. asking for an appointment & $1.66 \pm 0.91$ & $1.53 \pm 0.95$ & $1.76 \pm 0.98$ & $1.44 \pm 0.83$ & $1.60 \pm 0.93$ \\
\hline 9. approaching the dental office & $1.84 \pm 1.05$ & $1.68 \pm 1.01$ & $1.90 \pm 1.10$ & $1.64 \pm 0.95$ & $1.77 \pm 1.04$ \\
\hline 10. sitting in the waiting room & $1.76 \pm 0.98$ & $1.65 \pm 0.98$ & $1.83 \pm 1.00$ & $1.58 \pm 0.95$ & $1.71 \pm 0.98$ \\
\hline 12. smells of the dental office & $1.62 \pm 1.01$ & $1.62 \pm 1.09$ & $1.76 \pm 1.08$ & $1.47 \pm 0.98$ & $1.61 \pm 1.04$ \\
\hline 13. seeing the dentist & $1.64 \pm 0.88$ & $1.56 \pm 0.97$ & $1.74 \pm 0.98$ & $1.46 \pm 0.81$ & $1.61 \pm 0.92$ \\
\hline 14. seeing the injection & $2.86 \pm 1.28$ & $2.49 \pm 1.35$ & $2.64 \pm 1.29$ & $2.78 \pm 1.35$ & $2.71 \pm 1.32$ \\
\hline 15. feeling the injection & $2.79 \pm 1.22$ & $2.44 \pm 1.31$ & $2.60 \pm 1.24$ & $2.69 \pm 1.30$ & $2.64 \pm 1.27$ \\
\hline 16. seeing the drill & $2.39 \pm 1.25$ & $1.99 \pm 1.17$ & $2.37 \pm 1.16$ & $2.06 \pm 1.28$ & $2.22 \pm 1.23$ \\
\hline 17. hearing the drill & $2.19 \pm 1.23$ & $1.85 \pm 1.13$ & $2.17 \pm 1.13$ & $1.91 \pm 1.14$ & $2.05 \pm 1.14$ \\
\hline 18. feeling the vibration caused by the drill & $2.42 \pm 1.22$ & $2.04 \pm 1.23$ & $2.34 \pm 1.17$ & $2.17 \pm 1.30$ & $2.26 \pm 1.24$ \\
\hline 19. scaling & $1.52 \pm 0.81$ & $1.41 \pm 0.80$ & $1.57 \pm 0.82$ & $1.37 \pm 0.79$ & $1.47 \pm 0.81$ \\
\hline 20. general fear towards dentistry & $2.37 \pm 1.26$ & $2.05 \pm 1.10$ & $2.39 \pm 1.10$ & $2.07 \pm 1.07$ & $2.24 \pm 1.09$ \\
\hline
\end{tabular}


Table VII. DBS question scores $(n=406)$

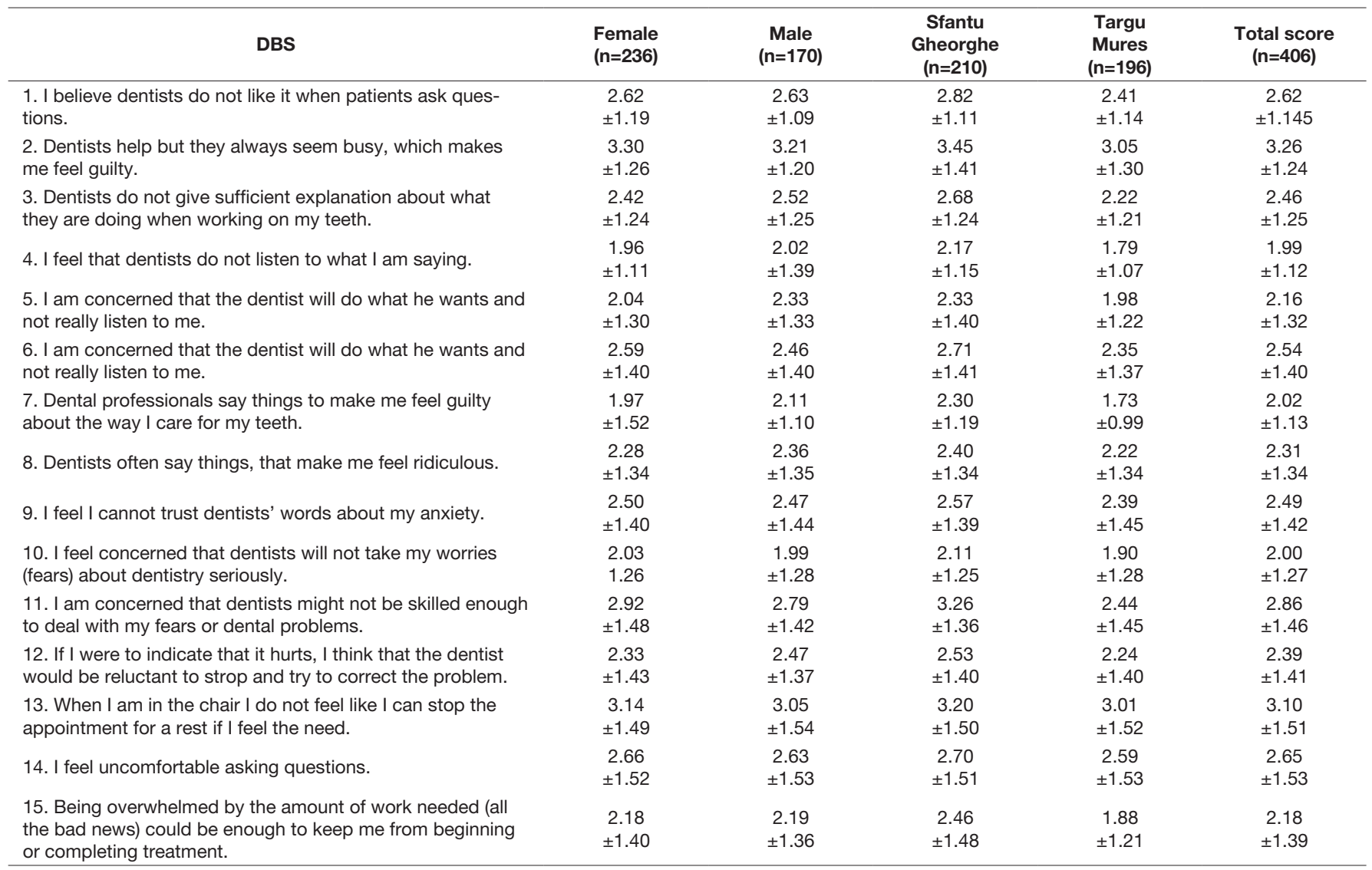

practitioner could be observed. Analysing from the viewpoint of gender, question no. 5, while from the point of view of domicile, questions no.1-7, 11, 12 and 15 showed statistically significant differences (independent t-test, $\mathrm{p}<0.05)$. Age was a significant factor in case of questions no. $1,3,7,10-12$ and 15 (one-way ANOVA, $\mathrm{p}<0.05$ ).

\section{Discussions}

The prevalence of DFA in children and adolescents in northern Europe has been reported between 3\% and 21\%, registering a maximum frequency at around 11 years of age and declining towards adolescence, being more frequent among girls [1]. In Singapore, $14 \%$ of children aged 10 to 14 presented high levels of dental fear [24], in Australia the prevalence of dental anxiety in the young adult population was reported to be $14.9 \%$, whereas in Canada and Russia it was only $12.5 \%$ and $12.6 \%$, respectively [7]. According to gender some authors found a higher level of anxiety in girls $[24,25]$, others could show this only in some ages [26], while there are researchers who did not find any differences [27]. It has been widely accepted that anxiety shows a tendency of decrease with age, as children grow older they may develop methods to control it $[28,29]$. In the same time, anxious mental constitution accentuates the grade of dental fear and children with high state anxiety are almost three times as likely to report dental fear than girls [24].

The findings of this survey suggest that dental fear and anxiety among Romanian children living in the central part of the country has its special aspects but is consistent with either the national and international results. A systematic method of evaluation being applied made easier the comparison with the already existing data. Although there were statistically significant differences between the two cities the study was performed in, the scores of the sample as a whole slightly exceeded or moved around the same level like in the other studies from the country or abroad.

Chrohnbach's alpha value (0.754) revealed a good inner consistency of the questionarries used in this survey. Besides, there was a positive correlation between anxiety and dental fear, similarly to the international results [27]. The lower correlation between the dental fear scales and the anxiety scales might suggest that the grade of dental fear is defined more by the circumstances of the dental treatment, than the general psychosocial influences. This observation could be supported also by the fact that the DBS (36.93) scores were high along the whole sample.

Overall the anxiety scoresof the assessed population of Romanian children from the middle part of the country were lower than those found in Hungarian children living in Romania (aged 12-19 years: STAI-S 39.7, STAI-T 43.8) [9]. Evaluating a smaller group of orthodontic patients aged 9-18 years, Vaida et al. found slightly higher scores for STAI-S (38.68), but much lower for STAI-T (36.71) [8]. The elevation of the state anxiety score compared to the trait anxiety in this case might have been due to the special circumsances of the orthodontic treatment. Otherwise, our results were somewhat higher but resembled in trait anxiety being higher than state anxiety to those found 
by the Hungarian researchers among children aged $8-15$ years: STAI-S:36.3, STAI-T: 38.8 [11]; and 14-18 years: STAI-S: 39.6, STAI-T: 41.5 [15].

It was revealed that our subjects presented the same dental anxiety scores as the Hungarian children from Hungary (aged 8-15 years: MDAS: 10.7 [17], aged 14-18 years: MDAS: 10.8 [15], Alberth's data for the 12- to14-year-old children MDAS: $10.3[10]$ ), but lower than the

Hungarian children's scores living in Romania as a minority (aged 12-19 years: MDAS:12.6 [9]). When validating the Romanian version of the Modified Dental Anxiety Scale, Mărginean and Filimon found a mean value of 9.30 on a young adult population aged 15-35 years [5]. This score is a little bit lower than the one found by us, however there is no information about the 15-18 years age group in this sample, so a concludent comparison cannot be made. In the same time Lazar et al. also used MDAS for the evaluation of a bigger sample of children aged 14-18 years in Timişoara, Romania, and stated that $18 \%$ of them presented no fear, $68 \%$ accused low, 10\% high and only $4 \%$ extremely high dental anxiety [6]. The results pointed outthat the majority of our subjects presented low or no fear at all (56.1\%) and only 5.6\% suffered from dental phobia, but in the same time a larger number of our subjects accused high dental anxiety (38.1\%). These results are similar to the ones found by Cerghizan et al. in adult population in Tîrgu Mureş [18, 19].

The mean score of DFS indicates the presence of a moderate dental fear along the sample. Only $12.5 \%$ suffered from phobia, while the rest presented low or moderate levels of fear in 50-50 percent. This is similar to the situation found in adults from Tîrgu Mureş [18, 19]. In addition to this, thefound DFS scores werelower (DFS: 38.68) than the ones measured by fellow Romanian researchers who investigated children. Markovics et al. measured DFS:50.6 on a sample with the same age ( $15.2 \pm 2.0$ years) [9], while Mărginean and Filimon found 40.57 for DFS, but the age of the subjects did not coincide with the one evaluated by us[4]. Making a comparison with Hungarian children, their scores were very similar to ours (aged 8-15 years DFS:40.4 [11], aged 14-18 years DFS:40.6 [15].

The scores obtained in this study slightly exceeded the ones found in the international literature where DAS was 8.6-9.3 [21, 30] and DFS 36.6-37.7 [30, 31].

Our results revealed that, except for DBS, females showed statistically significantly higher scores than males in case of every scale. DBS being higher in men is unusual [32], but the high DBS scores correlate with the high dental fear scores.

Regardingthe age, either in case of dental fear and anxiety scales, the 14-year-old group obtained the highest scores. Compared to this peak, the younger children presented even lower values than the older ones. On the one hand, this phenomenon does not correlate with Champan`s observation, who considered that the age of 11 years represents the turning point [1]. However, on the other hand the decreasing tendency towards the end of adolescence recognised by others could be observed as well $[1,27,33]$.

In the identification of the causes of dental fear and anxiety comes to our help the in detail analysis of DFS and DBS. The questions of DFS reflect the portions of the intervention, while DBS points to the dental practitioner who makes the treatment. In case of DFS, the specific pattern caracteristic for dental-phobics described by Johansson and Berggren cannot be observed on this sample. According to this, when scores given to questions referring to drilling exceed the ones about injection, respectively the score of the judgement of dentistry as a whole (question no. 20) being higher than the most fearful moment in the process indicate dental phobia [34]. Similarly to the literature, the questions referring to the injection and drilling obtained the highest scores also this time[9, 16, 18, 19, 35]. As for DBS, we have to mention that it is not widely used among children. This made difficult the comparison of the results, but also brings some interesting new information. Markovics et al. has used this type of evaluation in children and their results were similar to ours in the most objected questions, only the sequence was exactly the opposite, our subjects claimed the lack of time in front of the communication deficiencies [9].

\section{Conclusions}

This study brings new information about the features of DFA of children living in the central part of Romania, who were not evaluated until now. The systematic methods of survey made the interpretation of the findings more convenient. Interestingly, a particular feature of the sample was that the climax of anxiety shifted towards the middle of adolescence (14 years), the youngest children investigated seeming to be the least fearful.A huge improvement of the level of DFA could be observed in comparison to a very similar study performed in a sample of children of the Hungarian minority in Romania several years ago. In the same time dental fear and anxiety in children from Tîrgu Mureş moved around the same level as in adults from the same city $[18,19]$. As usual, injection and drilling were considered the most fearful parts of a dental treatment, but they did not approach the dental phobic features on this sample. DBS brought some new information about the relationship of the dentist with his/her little patients, who sensed lack of time and deficiencies in communication with the practitioner. This last conclusion could be considered the most important one, as it identifies the origins of dental fear and anxiety and it also may indicate the way to the solution.

\section{Acknowledgments}

The co-operation of the schools and children who participated in this study is gratefully acknowledged. This paper was supported by the Sectoral Operational Programme Human Resources Development 2007-2013 (SOP HRD), financed from the European Social Fund and by 
the Romanian Government under the contract number POSDRU/159/1.5/S/133377.

\section{References}

1. Chapman HR. Dental Fear in Children: a Proposed Model. British Dental Journal. 1999;187(8):408-412.

2. Spielberger CD, Gorduch RL, Lushene RE. Manual for the Strait-Trait Anxiety Inventory, Palo Alto, CA: Consulting Psychologist Press, 1970, pp. 25-30.

3. Smith T. Fear of Dental Care: Are We Making Any Progress. Journal of American Dental Association. 2003;134:1101-1108.

4. Mărginean I, Filimon L. Dental Fear Survey: a Validation Study on the Romanian Population. JPER. 2011;19(2):124-138.

5. Mărginean I, Filimon L. Modified Dental Anxiety Scale: a Validation study on Communities From the West Part of Romania. IJEPC. 2012; 2(1):102114.

6. Lazar CF, Babametis A, Bratu E, Deutsch P, Deutsch A, Papurica M. Measurement of Dental Fear and Assesing the Need of Pharmacological Management of Pain in Dentistry, a Survey of the Population in Timisoara. Medicine in Evolution. 2012;17(2):374-381.

7. Rãducanu AM, Feraru V, Herteliu C, Anghelescu R. Assessment of The Prevalence of Dental Fear and its Causes Among Children and Adolescents Attending a Department of Paediatric Dentistry in Bucharest. OHDMBSC. 2009;8(1):42-49.

8. Vaida L, Dalai C, Dima R. Evaluation of anxiety level in children and adolescents requesting orthodontic treatment. OHDMBSC. 2007;6(3):5761.

9. Markovics E, Markovics P, Fábián G, Vértes G, Fábián TK, Fejérdy P. Adatok a határon túli magyarság fogászati félelem értékeiről 12-19 éves korcsoportban. Fogorv Szle. 2005;98:165-169.

10. Alberth M, Gál N, Nemes J, Töviskes M, Máth J. 12-14 éves gyermekek "fogászati félelmének és szorongásának" hatása a fogazat állapotának alakulására. Fogorv Szle. 2002;95:113-117.

11. Fábián G, Fejérdy L, Fábián Cs, Kaán B, Gáspár J, Fábián TK. Fogászati kezeléstől való félelem epidemiológiai vizsgálata általanos iskolás (8-15 eves) korcsoportban. Fogorv Szle. 2003;96:129-133.

12. Fábián G, Fejérdy L, Kaán $B$, Fábián Cs, Tóth Zs, Fábián TK. Adatok általános iskolás (8-15 éves) gyermekek fogászati kezeléssel kapcsolatos félelmeinek hátteréről. Fogorv Szle. 2004;97:128-132.

13. Fábián TK, Handa T, Szabó $M$, Kelemen $P$, Kaán B, Fábián G. A dental Fear Survey (a "Fogászati félelem kerdőív") magyar fordítása, hazai populáción végzett mérések eredményei. Fogorv Szle. 1999;92:307-315.

14. Fábián TK, Kelemen P, Fábián G. A Dental Anxiety Scale hazai bevezetése. Magyar populáción végzett fogászati szorongás-epidemiológiai vizsgálatok. Fogorv Szle. 1998;91:43-52.

15. Fejérdy L, Fábián Cs, Kaán B, Fábián G, Gáspár J, Fábián TK. Epidemiológiai adatok néhány hazai szubpopuláció fogászati kezeléssel kapcsolatos félelmeiről. Fogorv Szle. 2003;96:277-281.

16. Gótai L, Beck A, Nartey DW, Molnár A, Lippmann AL, Fejérdy $P$, Hermann P, Fábián TK. Dental fear and anxiety scores of a Hungarian populationliving in the Hungarian-Slovakian border region. A pilot study. Fogorv Szle. 2012;105(1):19-27.

17. Székely M, Fazakas Z, Simon I. Az orvosi kommunikáció szerepe a fogorvosi kezelésektől való félelem és szorongás leküzdésében orvos, fogorvos és gyógyszerész hallgatók körében végzett felmérés. Orvostudományi Értesítő. 2005;78(4):565-569.

18. Cerghizan D. Cercetări asupra factorilor de comportament în tratamentul de reabilitare orală. PhD Thesis, UMF Tîrgu Mureș, 2009, pp:65-74.

19. Cerghizan D, Cerghizan R, Popșor S. Anxietatea dentară și durerea din antecedente. Revista de Medicină și Farmacie. 2008;54(3):113-114.

20. Corah NL. Development of a dental anxiety scale. J Dent Res. 1969;48(4):596

21. Kleinknecht RA, Klepac RK, Alexander LD. Origins and characteristics of fear of dentistry. J Am Dent Assoc. 1973;86:842-848.

22. Kleinknecht RA, Thorndike RM, McGlynn FD, Harkavy J. Factor analysis of the dental fear survey with cross-validation. J Am Dent Assoc. 1984;108:59-61.

23. Milgrom P, Weinstein P, Kleinknecht RA, Getz T. Treating fearful dental patients. Reston, (Virginia, USA): Reston Publishing Co. 1985, pp.31-36.

24. Chellappah NK, Milgrom P. Prevalence of dental anxiety and fear in children in Singapore. Community Dentistry and Oral Epidemiology. 2006;8(5):269-271.

25. Raadal M, Milgrom P, Weinstein P, Mancl L, Cauce AM. The prevalence of dental anxiety in children from low-income families and its relationship to personality traits. J Dent Res. 1995;74(8):1439-1443.

26. Neverlien PO. Dental anxiety, optimism-pessimism, and dental experience from childhood to adolescence. Com Dent Oral Epidemiol. 1994;22:263268.

27. Klinberg G, Berggren U, Carlsson SG, Noren JG. Child dental fear: cause related factors and clinical effects. Eur J Oral Sci. 1995;103:405-412.

28. Klingberg G, Broberg A. Dental fear/anxiety and dental behaviour management problems in children and adolescents: a review of prevalence and concomitant psychological factors. International Journal of Paediatric Dentistry. 2007;17(6):391-406.

29. Udoye $\mathrm{CH}$, Oginni FO. Dental anxiety among patients undergoing various dental treatments in a Nigerian teaching hospital. Journal of Contemporary Dental Practice. 2005;6(2):91-98.

30. Kunzelmann $\mathrm{KH}$, Duninger P. Dental fear and pain: effect on patient's perception of the dentist. Com Dent Oral Epidemiol. 1990;18:264-266.

31. Moore R, Brodsgaard I, Berggren U, Carlsson SG. Generalization of effects of dental fear treatment in a self-referred population of odontophobics. J Behav Ther Exp Psychiatr. 1991;22:243-253.

32. Johansson P, Berggren U, Hakeberg M, Jan-Michael H. Measures of dental beliefs and attitudes: their relationships with measures of fear. Com Dent Healt. 1992;10:31-39.

33. Cuthberth MI, Melamed BG. A screening device: children at risk for dental fears and management problems. J Dent Child (Chic). 1982;49:432-436.

34. Johansson P, Berggren U. Assessment of dental fear Acta Odontol Scand, 1992;50:43-49.

35. Firat D, Tunc EP, Sar V. Dental Anxiety Among Adults in Turkey. J Contemp Dent Pract. 2006;7(3):75-82. 